\title{
PHYTOCHEMICAL PROFILING AND ANTIBACTERIAL EFFICACY SCREENING OF AGLAIA MALABARICA SASIDH
}

\author{
ARCHANA ELAMKULAM RAVINDRAN*, JOHN ERNEST THOPPIL \\ Cell and Molecular Biology Division, University of Calicut, Kerala, India \\ Email: erarchana0@gmail.com
}

Received: 20 Oct 2017, Revised and Accepted: 12 Dec 2017

\begin{abstract}
Objective: Aglaia malabarica is an unexplored endemic forest tree belonging to the family Meliaceae. The present study was conducted to screen the phytochemical constituents of the leaf extract, to analyze the important secondary metabolites and to determine the antibacterial efficacy of the plant extract.
\end{abstract}

Methods: Antibacterial activity was studied using agar based disc diffusion method. Four strains of bacteria were used for the antibacterial study that includes Staphylococcus aureus, Pseudomonas aeruginosae, Proteus vulgaris and Bacillus megaterium.

Results: The presence of constituents like, carbohydrates, proteins, tannins, phenols, terpenoids, flavonoids, alkaloids and steroids were confirmed. Saponin was found to be absent. The secondary metabolites quantified were terpenoids, phenols and flavanoids, which were found in considerable amounts. The minimum inhibitory concentration (MIC) of all the bacteria studied was found to be $500 \mu \mathrm{g}$ methanolic leaf extract.

Conclusion: The plant extract was found to be highly potent against both the Gram positive and Gram negative strains and this property may be attributed to the potent phytochemicals revealed in the extract.

Keywords: Aglaia, Antibacterial, Meliaceae, Secondary metabolites, Leaf extract, Phytochemicals

(c) 2018 The Authors. Published by Innovare Academic Sciences Pvt Ltd. This is an open access article under the CC BY license (http://creativecommons.org/licenses/by/4.0/) DOI: http://dx.doi.org/10.22159/ijcpr.2018v10i1.24402

\section{INTRODUCTION}

Aglaia, belonging to the family Meliaceae, is a genus composed of mostly evergreen trees of which many are endemic to a particular geographical region. The genus comprises of over 120 species that are mainly distributed in the tropical and sub-tropical areas of the world. Though studies have revealed many of the bioactivities of various species of Aglaia, only a few works have been conducted in the south Indian species. Most of them are important economically as they have edible fruits, scented flowers or medicinal properties. The complex biological relationships with their dispersal agents showcase the ecological significance of these trees. Certain species of Aglaia have traditionally been used for their medicinal and healing properties such as the treatment of fever, diarrhoea, inflammation and wounds. Extracts have also been used as bactericides, insecticides and also in perfumery [1]. Aglaia malabarica Sasidh. is a less explored plant that is endemic to the northern region of Western Ghats in Kerala.

The active principles of many drugs of plant origin are secondary metabolites [2]. Hence, preliminary phytochemical profiling of the plant extracts for their major phytoconstituents is of much significance. The plants are able to sustain in different types of soils rich in microbes due to the antibacterial activity of these secondary metabolites. The qualitative phytochemical analysis reveals the chemical constitution of the plant extract and the estimation of the important secondary metabolites paves the way to investigate the biological activities of the plant.

The bactericidal potential of plant extracts has been proved immensely by previous researches. Man has been using plants as the remedy for different ailments from very ancient time onwards. Even though remedies for this have been developed so early, the resistance capacity developed in the microbes has necessitated the improvement in the existing drugs or innovation of new ones. Thus, the present study aims to explore the immediate chemical constituents in the plant extract and estimation of some important secondary metabolites present in it. Bactericidal activity against two gram-positive and two gram-negative bacteria that are common potential human pathogens was also analyzed. This is a novel study that reports the phytoconstituents and bioactivity of the plant Aglaia malabarica.

\section{MATERIALS AND METHODS}

\section{Collection of samples and bacteria}

The plant materials were collected from the tropical evergreen forests of Wayanad district, Kerala, India. The plant was identified at the Department of Botany, University of Calicut, Kerala, India (CALI no. 123754). The leaves were shade dried for seven days and crushed into powder using an electric blender and stored in a moisture free container at room temperature.

The bacterial strains were procured from Microbial Type Culture Collection and Gene Bank (MTCC), Chandigarh, India. The strains used for the study are Bacillus megaterium (MTCC 428), Staphylococcus aureus (MTCC 737), Proteus vulgaris (MTCC 426) and Pseudomonas aeruginosa (MTCC 424).

\section{Preparation of extracts}

The leaf was dried and powdered using an electric blender. Aqueous extract, as well as methanolic extracts, were used for the preliminary phytochemical profiling of the plant. The soxhlet extraction was followed by filtration, and then the plant extract was concentrated by evaporating to dryness under low pressure in a vacuum [3]. The dried methanolic extract was dissolved in DMSO and was used for antibacterial assays.

\section{Preliminary phytochemical profiling}

The presence of potent phytochemicals was screened using the aqueous and methanolic leaf extracts [4].

Test for carbohydrate: To $1 \mathrm{ml}$ of the aqueous extract, a few drops of Molisch's reagent was added followed by $2 \mathrm{ml}$ of conc. $\mathrm{H}_{2} \mathrm{SO}_{4}$ through the sides of the test tube and observed for the blue colouration. To confirm the presence of carbohydrates, a few drops of the test sample was treated with Benedict's reagent, boiled in a water bath and observed for the formation of a red precipitate.

Test for proteins: To the test sample, Millon's reagent was added and observed for the formation of white precipitate that turns red on heating. 
Test for carotenoids: $1 \mathrm{~g}$ of the powdered sample was extracted in 10 $\mathrm{ml}$ chloroform, filtered and was added with $85 \% \mathrm{H}_{2} \mathrm{SO}_{4}$. Formation of blue colour at the interface reveals the presence of carotenoids.

Test for saponins: Aqueous extract of the plant was taken in a test tube, diluted with $20 \mathrm{ml}$ distilled water and vigorous shaking was done. Presence of foam layer that persists on the top for $15 \mathrm{~min}$. is considered as the presence of the saponins.

Test for phenols: Extract was spotted on filter paper, a drop of phosphomolybdic acid was added to the spot and was exposed to ammonia vapour. The appearance of blue colouration reveals the presence of phenol. This was confirmed by another test in which a fraction of the sample was treated with $5 \%$ ferric chloride. The appearance of deep blue or black colour precipitate confirmed the presence of phenols in the extract.

Test for flavonoids: To $5 \mathrm{ml}$ of diluted ammonia solution, aqueous filtrate was added which was followed by a few drops of conc. $\mathrm{H}_{2} \mathrm{SO}_{4}$. The solution turning to yellow colouration on standing reveals the presence of flavonoids in the extract. This was confirmed by adding few drops of $20 \%$ sodium hydroxide to a portion of the extract. The presence of yellow colour that disappears on the addition of dil. $\mathrm{HCl}$ was considered as the confirmation of the presence of flavonoids.

Test for alkaloids: The test sample was treated with saturated picric acid (Hager's reagent) that produces a yellow precipitate reveals the presence of alkaloids in the test solution. It was confirmed by adding Wagner's reagent $(1.27 \mathrm{~g}$ iodine and $2 \mathrm{~g}$ potassium iodide in $100 \mathrm{ml}$ water) and observing the formation of reddish-brown precipitate or colouration.

Test for steroids: $1 \mathrm{ml}$ of the extract was treated with few drops of chloroform, acetic anhydride and conc. $\mathrm{H}_{2} \mathrm{SO}_{4}$ and observed for the formation of dark pink to red colour formation.

Test for terpenoids: Salkowski's test was conducted for this. $1 \mathrm{ml}$ of chloroform was added to $2 \mathrm{ml}$ of extract followed by few drops of conc. $\mathrm{H}_{2} \mathrm{SO}_{4}$. The appearance of reddish brown precipitate indicates the presence of terpenoids.

Test for tannins: To $2 \mathrm{ml}$ of sample $10 \%$ alcoholic ferric chloride solution was added and observed for the formation of blue/greenish colour solution (Braymer's test). The confirmatory test was done by adding few drops of $1 \%$ lead acetate to the test sample for the formation of a yellow precipitate.

\section{Quantitative phytochemical profiling of some important secondary metabolites}

Estimation of total phenolic content: The total phenolic content was estimated by using Folin-ciocalteu reagent assay [5] where gallic acid was used as the standard. $1 \mathrm{ml}$ of the test sample/standard solution of gallic acid was added with $0.5 \mathrm{ml}$ distilled water followed by $0.125 \mathrm{ml}$ $1 \mathrm{~N}$ Folin-ciocalteu reagent (Himedia), shaken well and allowed to stand for $6 \mathrm{~min}$. To this $1.25 \mathrm{ml}$ of $7 \% \mathrm{Na}_{2} \mathrm{CO}_{3}$ was added and the final volume was made up to $3 \mathrm{ml}$ using distilled water. The reaction mixture was mixed thoroughly, incubated in dark for $90 \mathrm{~min}$. and the absorbance was recorded at $760 \mathrm{~nm}$. Samples were analyzed in triplicates. The absorbance of various concentrations of the gallic acid standard was used to plot the calibration curve and the total phenolic content of the extract was calculated using the regression equation.
Estimation of total flavonoid content: To an aliquot of diluted sample/standard, $75 \mu \mathrm{l}$ of $7 \% \mathrm{NaNO}_{2}$ was added and kept for 6 min. To this $0.15 \mathrm{ml} 10 \% \mathrm{AlCl}_{3}$ was added, incubated for $5 \mathrm{~min}$. followed by the addition of $0.5 \mathrm{ml}$ of $1 \mathrm{M} \mathrm{NaOH}$. The final volume was made up to $2.5 \mathrm{ml}$ and the absorbance was taken at $510 \mathrm{~nm}$ to get the calibration curve from which total flavonoid content in the plant extract was estimated [6].

Estimation of total terpenoid content: Reaction mixture contains an aliquot of extract along with few drops of chloroform and $\mathrm{H}_{2} \mathrm{SO}_{4}$. The absorbance of this mixture was measured at $538 \mathrm{~nm}$. Linalool was used as the standard to obtain the calibration curve and the total terpenoid content in the extract was measured using the regression equation generated [7].

\section{Antibacterial assay}

The bacterial pure cultures were maintained in the nutrient agar medium, supplemented with beef extract, yeast extract and peptone. Subcultures of the bacterial strains were done at regular intervals and were incubated at room temperature. Streak plate method was used for the current study where the bacterial population was visible to the naked eye as a turbid layer on the medium.

Various concentrations of leaf methanolic extracts were tested for its bactericidal potential using agar based disc diffusion method. The methanolic extract was dissolved in DMSO (Dimethyl sulfoxide) and various concentrations of $100 \mu \mathrm{g} / \mathrm{ml}, 200 \mu \mathrm{g} / \mathrm{ml}, 500 \mu \mathrm{g} / \mathrm{ml}, 1000$ $\mu \mathrm{g} / \mathrm{ml}, 1500 \mu \mathrm{g} / \mathrm{ml}, 2000 \mu \mathrm{g} / \mathrm{ml}$, were prepared. DMSO alone was used as the negative control while the tetracycline discs (Himedia) were used as positive control. The discs made of Whatman filter paper no.1 were dipped in the extracts of various concentrations and air dried for a few minutes. The discs were then transferred to the streak plates and incubated at room temperature for $24 \mathrm{~h}$. The least concentration that inhibited the growth of the colony was considered as the minimum inhibitory concentration (MIC).

\section{RESULTS}

The preliminary phytochemical analysis of the methanolic leaf extract of the plant revealed the presence of major secondary metabolites along with the primary metabolites like carbohydrates and proteins but saponins were not detected (table 1). The presences of these components in a very prominent manner lead to the quantification of the major ones. The quantified ones were terpenoids, flavonoids and phenols (table 2). The leaf methanolic extract of the plant contained the terpenoids of $162.32 \pm 22.81$ mglinalool/g dry weight of the sample (DW). The flavonoid content was estimated to be $95.67 \pm 5.09 \mathrm{mg} \mathrm{QE} / \mathrm{g} \mathrm{DW}$, while the total phenol was found as $118.59 \pm 13.03 \mathrm{GAE} / \mathrm{g}$ DW of the extract.

The antibacterial study of the methanolic extract was carried out by using DMSO as the vehicle solvent. Extracts of several concentrations were screened for its bactericidal efficacy by determining MIC. The plant extract showed inhibition of bacterial growth against all the four strains included in the study, starting from the concentration of $500 \mu \mathrm{g}$. Thus, the minimum inhibition concentration (MIC) of the methanolic extract was found to be $500 \mu \mathrm{g}$. The range of the zone of inhibition formed around the discs was $8.3 \pm 0.7 \mathrm{mmto} 10.3 \pm 0.7 \mathrm{~mm}$ at the point of MIC, including the diameter of the filter paper $(5 \mathrm{~mm})$. There was no zone formed in the concentrations lower than $500 \mu \mathrm{g}$. All the concentrations above the MIC showed considerable bactericidal potential which was directly proportional to the concentrations used (table 3 ).

Table 1: Preliminary phytochemical analysis of Aglaia malabarica leaf

\begin{tabular}{lll}
\hline S. No. & Test component & Presence \\
\hline 1. & Carbohydrate & + \\
2. & Protein & + \\
3. & Carotenoids & + \\
4. & Saponins & + \\
5. & Phenols & + \\
6. & Flavonoids & + \\
7. & Alkaloids & + \\
8. & Steroids & + \\
9. & Terpenoids & + \\
10. & Tannins & + \\
\hline
\end{tabular}

+present,-absent 
Table 2: Quantitative phytochemical analysis of Aglaia malabarica leaf

\begin{tabular}{ll}
\hline Chemical constituent & Total content in leaf extract \\
\hline Terpenoids (LE/g DW) & $162.32 \pm 22.81^{\mathrm{b}}$ \\
Flavonoids (QE/g DW) & $95.67 \pm 5.09^{\mathrm{b}}$ \\
Phenols (GAE/g DW) & $118.59 \pm 13.03^{\mathrm{b}}$ \\
\hline
\end{tabular}

Table 3: Antibacterial activity of methanolic leaf extract of Aglaia malabarica

\begin{tabular}{|c|c|c|c|c|}
\hline \multirow[t]{2}{*}{ Conc. of the plant extract } & \multicolumn{4}{|c|}{ Zone of inhibition (in $\mathrm{mm}$ ) } \\
\hline & B. megaterium & P. aeuriginosae & S. aureus & P. vulgaris \\
\hline control & $29.7 \pm 8.8^{\mathrm{b}}$ & $28.7 \pm 0.3^{\mathrm{b}}$ & $26.0 \pm 1.2^{\mathrm{a}}$ & $39.0 \pm 0.6^{c}$ \\
\hline $100 \mu \mathrm{g}$ & 0 & 0 & 0 & 0 \\
\hline $200 \mu \mathrm{g}$ & 0 & 0 & 0 & 0 \\
\hline $500 \mu \mathrm{g}$ & $8.7 \pm 0.3^{\mathrm{a}, \mathrm{b}}$ & $8.3 \pm 0.7^{a}$ & $10.3 \pm 0.7^{b}$ & $9.3 \pm 0.6^{\mathrm{a}, \mathrm{b}}$ \\
\hline $1000 \mu \mathrm{g}$ & $11.0 \pm 0.6^{\mathrm{a}}$ & $11.3 \pm 0.9^{a}$ & $10.0 \pm 0.6^{\mathrm{a}}$ & $12.0 \pm 0.1^{\mathrm{a}}$ \\
\hline $1500 \mu \mathrm{g}$ & $19.0 \pm 0.6^{\mathrm{a}}$ & $10.0 \pm 0.6^{\mathrm{a}}$ & $15.0 \pm 0.6^{b}$ & $17.0 \pm 0.7^{b}$ \\
\hline $2000 \mu \mathrm{g}$ & $21.0 \pm 0.6^{c}$ & $17.7 \pm 0.3^{\mathrm{b}}$ & $15.7 \pm 0.3^{\mathrm{a}}$ & $17.0 \pm 0.6^{\mathrm{a}, \mathrm{b}}$ \\
\hline
\end{tabular}

\section{DISCUSSION}

Qualitative analysis of the plant extracts has been attempted as the preliminary constituent verification test. The phytochemical constituents of several other species of Aglaia have been reported earlier [8-11]. Most researches on the bioactivities of various species of Aglaia, like molluscidal, anti-inflammatory, insecticidal and antimicrobial activities have been supported with their chemical constituents [12-14] and this reveals the importance of the phytochemicals of this particular genus in therapeutics.

The antibacterial potential of the plant extract was proved against all the four tested strains of bacteria. The diameter of the zone of inhibition was found to be directly proportional to the concentration of the drug. It is evident from the previous reports that the secondary metabolites, particularly, the flavonoids, phenols and terpenoids are the major factors that enhance the plant to exhibit the defence mechanism against the microbes. Many plants belonging to the family Meliaceae are proved to have the bactericidal efficacy [15-17]. The present study reveals the antibacterial activity of the plant extract to both Gram positive as well as Gram negative bacteria that are potential human pathogens. The plant extract has proved to have a considerably high amount of potential phytoconstituents like flavonoid, phenol and terpenoids. The bactericidal potential might be due to the synergistic effect of these secondary metabolites present in the plant extract.

\section{ACKNOWLEDGEMENT}

The authors are grateful to the Department of Botany, the University of Calicut for the facilities provided and funding the present study.

\section{AUTHORS CONTRIBUTIONS}

All the author have contributed equally

\section{CONFLICT OF INTERESTS}

The authors declare that they have no conflict of interest

\section{REFERENCES}

1. Satasook C, Isman MB, Ishibashi F, Medbury S, Wiriyachitra $P$, Towers GH. Insecticidal bioactivity of crude extracts of Aglaia species (Meliaceae). Biochem Systematics Ecol 1994;22:121-7.

2. Dobelis P, Madl JE, Manners GD, Pfister JA, Walrond JP. Antagonism of nicotinic receptors by Delphinium alkaloids. Neurosci Abstracts 1993;631:12.

3. JB Harborne. Phytochemical methods. 3rd ed. London: Chapman and Hall; 1998.

4. Evans WC. Trease and Evans. Pharmacognosy. $15^{\text {th }}$ ed. Toronto: Harcourt Pub Ltd; 2002. p. 1-40.
5. Oueslati S, Ksouri R, Falleh H, Pichette A, Abdelly C, Legault J. Phenolic content, antioxidant, anti-inflammatory and anticancer activities of the edible halophyte Suaeda fruticosa forssk. Food Chem 2012;132:943-7.

6. Dewanto $\mathrm{V}, \mathrm{Wu} \mathrm{X}$, Adom KK, Liu RH. Thermal processing enhances the nutritional value of tomatoes by increasing total antioxidant activity. J Agric Food Chem 2002;50:3010-4.

7. Ghorai N, Chakraborty S, Gucchait S, Saha SK, Biswas S. Estimation of total terpenoids concentration in plant tissues using a monoterpene, linalool as a standard reagent. Protoc Exch 2012. Doi:10.1038/protex.2012.055.

8. Bacher M, Hofer O, Brader G, Vajrodaya S, Greger H. Thapsakins: possible biogenetic intermediates towards insecticidal cyclopenta [b] benzofurans from Aglaia edulis. Phytochemistry 1999;52:253-63.

9. Joycharat N, Thammavong S, Voravuthikunchai SP, Plodpai $\mathrm{P}$, Mitsuwan W, Limsuwan S, et al. Chemical constituents and antimicrobial properties of the essential oil and ethanol extract from the stem of Aglaia odorata lour. Natl Prod Res 2014;28:2169-72.

10. Kim S, Chin YW, Su BN, Riswan S, Kardono LB, Afriastini JJ, et al. Cytotoxic flavaglines and bisamides from Aglaia edulis. J Natl Prod 2006;69:1769-75.

11. Zhang $\mathrm{H}, \mathrm{Xu} \mathrm{HH}$, Song ZJ, Chen LY, Wen HJ. Molluscicidal activity of Aglaia duperreana and the constituents of its twigs and leaves. Fitoterapia 2012;83:1081-6.

12. Liu S, Wang H, Zuo WJ, Zhao YX, Li XN, Mei WL, et al. Two new rocaglamide derivatives from twigs of Aglaia odorata var. microphyllina. Phytochem Lett 2013;6:5-8.

13. Kim S, Su BN, Riswan S, Kardono LB, Afriastini JJ, Gallucci JC, et al. Edulisones $\mathrm{A}$ and $\mathrm{B}$, two epimeric benzo [b] oxepine derivatives from the bark of Aglaia edulis. Tetrahedron Lett 2005;46:9021-24.

14. Yodsaoue O, Sonprasit J, Karalai C, Ponglimanont C, Tewtrakul S, Chantrapromma S. Diterpenoids and triterpenoids with potential anti-inflammatory activity from the leaves of Aglaia odorata. Phytochemistry 2012;76:83-91.

15. Rajasekaran C. Investigations on antibacterial activity of leaf extracts of Azadirachta indica A. Juss (Meliaceae): a traditional medicinal plant of India. Ethnobot Leaflets 2008;12:1213-7.

16. Sharma M, Mohan V, Abraham M, Joshy PJ, Reghuvaran DK. Antimicrobial screening of different extracts of South Indian medicinal plants of Meliaceae. J Med Plants Res 2011;5:688-95.

17. Lavate SM, Jadhav RB, Torane R, Kale AA, Shendkar CD Deshpande NR. In vitro antibacterial activity of Aglaia lawii leaves extracts against bacterial pathogens. J Pharm Res 2012;5:3810-2. 